\title{
Intention to Use Microsoft Teams in the Online Learning System for Students of Universitas Tarumanagara During the COVID-19 Pandemic
}

\author{
Katherine Laurencia ${ }^{1}$ Sudarto Sudarto ${ }^{1 *}$ \\ ${ }^{1}$ Faculty of Communication Science, Universitas Tarumanagara, Jakarta 11440, Indonesia \\ *Corresponding author. Email: sudarto@fikom.untar.ac.id
}

\begin{abstract}
The development of communication technology currently plays a very important role in fulfilling human life. The current Covid-19 pandemic situation makes communication technology indispensable in the world of education for the implementation of distance learning systems, such as the use of Microsoft Teams. The use of Microsoft Teams as an educational system platform at Universitas Tarumanagara can be a solution to overcome obstacles in the learning process during the Covid-19 pandemic. This study aims to discuss Intention To Use in using Microsoft Teams for online learning systems. Universitas Tarumanagara students during the Covid-19 pandemic. The main theory in this research is the Technology Acceptance Model which is used to examine the effect of technology acceptance on the use of Microsoft Teams. This study uses a quantitative approach with the method of analysis of the Structural Equation Modeling (SEM) path using SmartPLS3 software. This study used a survey method with data collection using an online questionnaire (self-administered questionnaire) with 123 respondents. The results of this study indicate that the variables Perceived Ease of Use, Perceived Usefulness, Attitude Towards Using have a significant effect on Intention To Use, so that the Technology Acceptance Model in using Microsoft Teams is accepted.
\end{abstract}

\section{Keywords: Technology Acceptance Model, Intention to Use, Communication Technology, Microsoft Teams}

\section{INTRODUCTION}

The development of communication technology has entered the digital era 4.0 which is currently experiencing rapid and rapid progress from time to time. According to Roger [1] defines communication technology as hardware in an organizational structure that contains social values, which allow each individual to collect, process, and exchange information with other individuals. The development of advances in communication technology cannot be avoided in human life and is even inherent in human life. In every stage of the development of communication technology will have a significant influence on human development, such as lifestyle, attitudes and behavior.

One example of communication technology is the internet. The Internet is a network of computer systems that are interconnected as a very important online communication tool for humans today. Humans tend to want to use things they think are practical and fast. The advantages possessed by the internet make it easier for humans to reach a wide communication network via online. An example of an internet-based communication technology is Microsoft Teams. Microsoft Teams is a communication platform that provides new experiences, bringing together the people, conversations, content, and tools needed in a team so they can collaborate easily to achieve more. Microsoft Teams is available as a preview to eligible Office 365 commercial customers starting November 2, 2016, while the publicly available services opened in the first quarter of 2017.

Currently, almost all countries in various parts of the world are being hit by a virus outbreak, namely Covid-19. This virus has spread globally so that it can be said to be a pandemic. Indonesia is one of the countries affected by the virus outbreak. Almost all sectors in various fields in Indonesia have been seriously affected by the Covid-19 virus, one of which is in the education sector. In the current situation, it does not allow students to carry out a face-toface learning system, the internet can be used and utilized as a learning method that can be done online or known as elearning. E-learning is information and communication technology in enabling students to be able to learn flexibly [2]. It is hoped that the internet media that provides various means for the online learning systems can be used appropriately and useful in the current Covid-19 pandemic. The presence of the Microsoft Teams platform can be an option for educational institutions to implement an online learning system. All learning programs implemented will follow the system available on the Microsoft Teams platform. There are also several other applications that can be options in supporting distance learning systems, such as Zoom, Skype, Google Meet, and other applications. However, the Microsoft Team platform was chosen to be 
one of the mandatory applications for conducting distance learning at Universitas Tarumanagara. The application of the use of the Microsoft Teams platform at Universitas Tarumanagara is expected to be able to optimize internet media used as a source of knowledge in online learning systems in this technological era. In research Surahman [3], states that technology in relation to the internet is able to change the way users think and its role in shaping user behavior.

The application of the use of Microsoft Teams above can be seen from several studies that discuss the use of technology by using existing theories, one of which is the Technology Acceptance Model. This research uses the Technology Acceptance Model theory to look at factors such as perceived ease of use and perceived usefulness which can influence individual attitudes towards technology use and the intention to reuse the technology.

Whether the use of Microsoft Teams for online learning systems during the Covid-19 pandemic can achieve the learning objectives seen from Intention To Use? Did the technology can acceptable and makes it easier for students to study? Thus, in this study, the researcher wanted to see the acceptance and the ease of use of technology in Universitas Tarumanagara students based on the Technology Acceptance Model Theory (TAM).

\subsection{Related Work}

\subsubsection{Technology Acceptance Model in Digital Library System}

This research discusses the application of digital library technology, which is a library that can be accessed online using a computer network and has many collections such as books in the form of file formats and other information that can be accessed at any time and wherever.This study uses the Technology Acceptance Model theory to see student acceptance in several educational institutions that implement the use of the digital library. In addition, this study refers to the Technology Acceptance Model research model developed by Davis in 1993 using four variables, namely perceived ease of use, perceived usefulness, attitude toward using and replacing behavioral intention and behavioral variables into acceptance variables. The results obtained are from 5 hypotheses that have been tested, there are 4 hypotheses accepted and have a significant effect and 1 hypothesis is rejected, namely the influence of perceived ease to acceptance.

\subsubsection{Technology Acceptance Model ini E- Learning System}

This study discusses the application of e-learning among students in Jordanian Universities. This study uses the Technology Acceptance Model theory to see student acceptance in using the e-learning system. In addition, this study refers to the Technology Acceptance model research model developed by Davis in 1989 using 4 variables, namely perceived ease of use, perceived usefulness, attitude toward using, and intention to use. The results obtained are from the 5 hypotheses tested, there are 2 insignificant hypotheses, namely the effect of perceived usefulness on attitude towards using and the effect of attitude towards using on intention to use.

\subsubsection{Technology Acceptance Model in Digital Media Behavior}

This study discusses the behavior in implementing the use of digital media technology as a learning medium that must fulfill the three elements of the tridarma of higher education among Unisba lecturers where each lecturer must be able to adapt to the development of existing information technology. This study uses the Technology Acceptance Model theory to see and get an overview of the behavior in using digital media in the implementation of tridarma in Unisba universities. In addition, this study refers to the Technology Acceptance Model research model developed by Davis in 1989 using five variables, namely perceived ease of use, perceived usefulness, attitude, behavior intention to use, and behavior to use. The results obtained are that there are differences between the behavior and the Unisba lecturers have not fully used digital media in fulfilling the tridarma of higher education in Unisba.

\subsection{Our Contribution}

This paper presents research that is being carried out by researchers relating to the learning system in the education sector during the Covid-19 pandemic situation. In terms of the education sector during the Covid-19 pandemic, researchers want to test the Technology Acceptance Model theory model proposed by Fred Davis regarding the use of technology that is associated with the context of the online learning system implemented in Indonesia in the Covid-19 pandemic situation. In addition, researchers also want to see the acceptance of a learning technology, namely Microsoft Teams, compared to other similar learning technologies that are more popular, such as Skype, Zoom, Google Meet, and others that can support online learning systems that can be used as solutions for the sector education in the face of the Covid-19 pandemic situation.

\subsection{Paper Structure}

Other papers are organized as follows. Section 2 presents the related theories in this researches, the research model framework, and the hypotheses that are derived. Then 
several methods are used to test the constructs and hypotheses used in this study which are listed in Section 3. Section 4, namely the results of the tests that have been carried out in testing whether the hypothesis is accepted or not and the discussion related to the theory and research results and according to the existing situation. Finally, Section 5 concludes the results of the study.

\section{BACKGROUND}

\subsection{Media Ecology}

According to Marshall McLuhan [4], said that the presence of media technology can be a determinant in shaping human life. This media ecology theory adheres to the main principle or idea to see that society cannot be separated from the influence of media technology. Based on McLuhan's thoughts [5], there are 3 (three) basic assumptions, namely:

(1) The media encompasses every action in society. According to McLuhan's perspective, this assumption is that the media is present and embedded in people's daily lives.

(2) The media enhance our perceptions and govern our experiences.

This assumption explains that the Media Ecology Theory views the media as having a direct influence on humans.

(3) The media unites the whole world.

This assumption explains that events that occur in various other parts of the world can be known or spread widely to other parts of the world or are known as global villages. Global Village explained that there are no more boundaries between any part of the world regarding what to do so that everything that is done in other parts of the world can be easily identified and spread quickly to other people in other parts of the world.

\subsection{Computer-Mediated Communication}

Computer Mediated Communication (CMC) can be simply defined as communication that occurs between individuals and individuals using a computer network [6]. In the book The Handbook of the Physcology of Communication Technology says that CMC is a theoretical model of online interpersonal interaction which is used to explain how individuals and groups form an impression and develop relationships through text-based electronic communication. The premise of social information processing theory forms the basis for following several models, including the hyperpersonal CMC model [7]. The CMC pattern according to Joseph Walther in social information processing theory or more often abbreviated as SIP (Social Information Process) says that in CMC, communicators describe themselves in a socially beneficial way with the aim of attracting attention from message recipients and developing interactions in the future with the message recipient. According to Joseph Walther, there are three types of communication perspectives that discuss CMC in his book Communication Theory (History, Methods, and Applied in Mass Media) [8], namely:

a. Impersonal Communication

Impersonal communication considers that communication carried out online is considered less effective in the personal aspect because the internet does not support nonverbal signals in establishing interpersonal interactions, whereas in face-to-face communication, communication actors tend to use more nonverbal language in communicating, such as voices, expressions face, intonation, distance and more

b. Interpersonal Communication

Interpersonal communication is said to be a process of exchanging messages between two or more people who communicate. There are 2 types of interpersonal communication, namely verbal and non-verbal.

c. Hyperpersonal Communication Hyperpersonal communication indicates that online communication has an impact on communicators in communication. According to [7] the hypersonal communication model proposes four simultaneous communication routines that attempt to explain CMC support for relationships with relatively greater levels of desire and intimacy than offline communication, consisting of:

(1) Sender (Messenger / communicator)

Text based CMC provides selective self presentation facility. Online users can only send the desired (non-verbal) cues so that they do not need to express their speaking behavior physically (verbal).

(2) Receiver (recipient of the message)

Receiver and sender are almost the same and the difference is only in the role. Receiver and sender both have the freedom to form their own identity. In hyperpersonal communication, receivers at one time can perform various activities, namely being the recipient of the sender's message, single messages or being part of mutual participants or even the source of mass communication. The communication pattern used by the receiver aims to maintain a communication in carrying out the relationship.

(3) Channel (channel or media used) In hypersonal communication, there are 2 types of communication, namely verbal and non-verbal. Verbal language is used in written form (text) and can also use voice / audio contained in the CMC application, while non-verbal language uses written forms, punctuation, emoticons, animation as a form to understand the meaning of the message to be conveyed.

(4) Feedback

The most important thing in communication is a response from the recipient of the message to the message that has been conveyed. Feedback can be 
positive or negative depending on the message the communicator will send to the recipient of the message.

\subsection{Technology Acceptance Model}

The Technology Acceptance Model (TAM) was first introduced by Fred Davis in 1986. TAM is known as a model related to the acceptance and use of technology in predicting user behavior in using information technology [9]. According to Davis, F., Bagozzir, R. \& Warshaw, P. [9], the Technology Acceptance Model (TAM) is an adoption of Theory of Reasoned Action (TRA). According to TRA, the resulting behavior is driven by the user's intention to behave which can be seen from the individual attitudes and subjective norms of the behavior. Attitude is the feeling that a person experiences, both positive and negative, about doing a desired behavior and subjective norm is the perception of a person who thinks whether he should do the behavior in question or vice versa. TAM is built on 2 main variable elements consisting of perceived ease of use and perceived usefulness. TAM has 4 variables consisting of:

a. Perceived Ease of Use

A level where individuals feel that the use of a certain system is easy to understand and not difficult to learn.

b. Perceived Usefulness

The level at which an individual believes that the use of a system does not require any effort (free of effort). This can be seen from the extent to which an individual believes that using a certain system can improve their performance

c. Attitude Towards Using

The level where attitudes affect individual behavior in using technology which can be in the form of acceptance or rejection of using technology for their work.

d. Behavior Intention to Use

An individual has a tendency to behave in terms of influencing the intention to direct himself in using technology.

Based on the above model adopted from Davis, the components in TAM show that Perceived Usefulness and Perceived Ease of Use can predict the effect of Attitude Towards Using. Perceived Usefulness directly affects Intention To Use which is also a determining factor in the use of technology.

If the level of Perceived Usefulness is high enough, it can result in a more positive attitude towards technology use. Perceived Usefulness can be a direct determinant of Intention To Use. However, Perceived Usefulness can also be influenced indirectly and must pass the determinants of Attitude Towards Using to arrive at Intention To Use. Thus, it can be concluded that:

Hypothesis 1 :

H0: Perceived Usefulness (PU) does not have a significant relationship to Intention to Use (ITU)
H1: Perceived Usefulness (PU) has a significant relationship with Intention to Use (ITU)

Hypothesis 2:

H0: Perceived Usefulness (PU) does not have a significant relationship with Attitude Toward Using (ATU)

$\mathrm{H}$ 2: Perceived Usefulness (PU) has a significant relationship with Attitude Toward Using (ATU)

According to Park and Chang et al. [9], Perceived Ease of Use is used as a direct determinant of Attitude Towards Use. Increased perceptions of the perceived ease of use of technology not only influence intentions, but lead to positive attitudes. According to Sek et al. and Lee et al. [9], the perceived ease of use indirectly affects perceived usefulness to get intention to use. So that the hypothesis that is formed is:

Hypothesis 3:

H0: Perceived Ease of Use (PEOU) does not have a significant relationship with Attitude Toward Using (ATU)

H3: Perceived Ease of Use (PEOU) has a significant relationship with Attitude Toward Using (ATU)

Hypothesis 4:

H0: Perceived Ease of Use (PEOU) does not have a significant relationship to Perceived Usefulness (PU)

H4: Perceived Ease of Use (PEOU) has a significant relationship with Perceived Usefulness (PU)

Attitudes towards the use of technology (ATU) drive behavior and refer to how individuals respond to or ignore an object. Every effort made to implement technology is contingent on user attitude engagement (ATU). If a user believes that technology is not sufficient to meet his needs, that individual will refuse to use it. The linkage of technology in order to achieve success requires users to be able to have a positive attitude towards it. Thus, the hypothesis is derived, namely:

Hypothesis 5:

H0: Attitude Towards Using (ATU) does not have a significant relationship to Intention to Use (ITU)

H5: Attitude Towards Using (ATU) has a significant relationship to Intention to Use (ITU)

\subsubsection{Theoretical Framework}

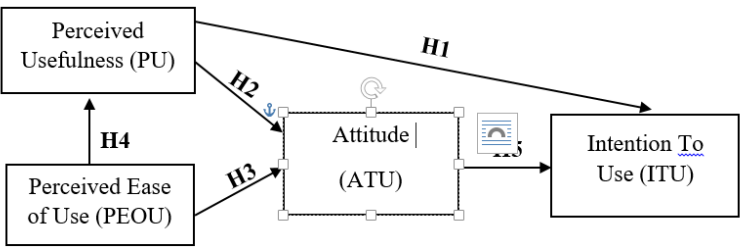

Figure 1 Research Model Technology Acceptance Model 


\section{METHODS}

The research approach used by researchers is a quantitative survey method. According to [10], survey research is research conducted in a large or small population. According to [10], Population is an area of generalization consisting of objects / subjects with certain qualities and characteristics determined by researchers so that they can be studied and conclusions can be drawn. In this study, the researcher chooses active students who are spread across several faculties at Universitas Tarumanagara. Researchers used non-probability sampling methods with purposive sampling technique, namely the sampling technique as a source of data through certain considerations. Researchers took samples by distributing questionnaires online (selfadministered questionnaire) using a sample of 123 respondents.

In this study, researchers used Structural Equation Modeling (SEM) data analysis techniques run with SmartPLS3 software. PLS is a tool used to analyze variantbased structural equations (SEM) which can simultaneously test the measurement model and structural model simultaneously. The data analysis in this study is an inferential statistical analysis measured using SmartPLS3 software for model analysis, starting from the measurement model (outer model), the model structure (inner model), to hypothesis testing. Test results from these measurements to see whether a hypothesis is accepted or not.

\section{FINDINGS AND DISCUSSIONS}

The results of the study using path analysis show that the variables Perceived Ease of Use, Perceived Usefulness, Attitude Towards Using have a significant effect on Intention To Use, so that the Technology Acceptance Model theory in using Microsoft Teams is accepted. These results are obtained from testing using validity, reliability, testing structural model equations, testing structural models between constructs, and testing hypotheses.

This study uses validity and reliability tests. The validity test is to explain the validity of the construct by looking at the extent to which the tool is able to measure a construct to be measured [11]. A study is said to be valid if the Average Variance Extracted (AVE) value is $>0.5$, while the reliability test looks at a measurement to what extent it can give relatively no different results, if the same object is remeasured [11]. A study is said to be reliable if it has a Cronbach's Alpha value > 0.6 and a Composite Reliability value $>0.8$.

Table 1 The results of the construct validity and reliability

\begin{tabular}{lcccc}
\hline & $\begin{array}{c}\text { Cronbach's } \\
\text { Alpha }\end{array}$ & rho_A & $\begin{array}{c}\text { Composite } \\
\text { Reliability }\end{array}$ & $\begin{array}{c}\text { Average } \\
\text { Variance } \\
\text { Extracted (AVE) }\end{array}$ \\
\hline $\begin{array}{l}\text { Attitude Towards } \\
\text { Using }\end{array}$ & 0.873 & 0.875 & 0.908 & 0.666 \\
\hline $\begin{array}{l}\text { Intention To Use } \\
\begin{array}{l}\text { Perceived Ease of } \\
\text { Use }\end{array}\end{array}$ & 0.842 & 0.845 & 0.894 & 0.678 \\
\hline $\begin{array}{l}\text { Perceived Usefulness } \\
\text { Peren }\end{array}$ & 0.913 & 0.915 & 0.935 & 0.595 \\
\hline
\end{tabular}

Based on the test results using SmartPLS3, it can be concluded that the Attitude Towards Using variable, Intention to Use variable, Perceived Ease of Use variable, and Perceived Usefulness variable are declared valid and reliable because they have an Average Variance Extracted value $>0.8$, Cronbach's Alpha value $>0,6$ and the value of Composite Reliability $>0.8$.

In this study, hypothesis testing was also carried out by looking at the results of the $\mathrm{T}$ test with the bootstrapping procedure. In this method, sampling is carried out repeatedly (re-sampling) is carried out 500 times. With bootstrapping samples, it is possible to estimate the coefficients in PLS-SEM to test their significance (Henseler $\&$ Chin, 2010) [12].

The p-value approach is used in analyzing the significance of a hypothesis if the p-value $<0.05$ can be said to be significant or the hypothesis is accepted, if the p-value $>$ 0.05 can be said to be insignificant or the hypothesis is rejected. In addition, each hypothesis can be accepted and said to be significant if $\mathrm{t}$ count $>\mathrm{t}$ table, where $\mathrm{t}$ table $=1.96$ which can be accepted with a confidence level of $95 \%$.

Table 2 The result of path coefficients test

\begin{tabular}{|c|c|c|c|c|c|}
\hline & $\begin{array}{l}\text { Original } \\
\text { Sample } \\
\text { (O) }\end{array}$ & $\begin{array}{c}\text { Sample } \\
\text { Mean } \\
(M)\end{array}$ & $\begin{array}{l}\text { Standard } \\
\text { Deviation } \\
\text { (STDEV) }\end{array}$ & $\begin{array}{c}\text { TStatistics } \\
(\mid \mathrm{O} / \mathrm{STDEV})\end{array}$ & P Values \\
\hline $\begin{array}{l}\text { Attitude Towards } \\
\text { Using -> } \\
\text { Intention To Use }\end{array}$ & 0.545 & 0.539 & 0.097 & 5.616 & 0.000 \\
\hline $\begin{array}{l}\text { Perceived Ease of } \\
\text { Use } \rightarrow>\text { Attitude } \\
\text { Towards Using }\end{array}$ & 0.380 & 0.373 & 0.093 & 4.074 & 0.000 \\
\hline $\begin{array}{l}\text { Perceived Ease of } \\
\text { Use }->\text { Perceived } \\
\text { Usefulness }\end{array}$ & 0.620 & 0.624 & 0.061 & 10.145 & 0.000 \\
\hline $\begin{array}{l}\text { Perceived } \\
\text { Usefulness -> } \\
\text { Attitude Towards } \\
\text { Using }\end{array}$ & 0.495 & 0.502 & 0.080 & 6.150 & 0.000 \\
\hline $\begin{array}{l}\text { Perceived } \\
\text { Usefulness -> } \\
\text { Intention To Use }\end{array}$ & 0.347 & 0.353 & 0.102 & 3.407 & 0.001 \\
\hline
\end{tabular}

Based on the results of data processing, all variables have a $\mathrm{p}$-value $<0.05$ and a t value $>1.96$. Then it can be concluded that:

(1) There is a significant relationship between the Perceived Usefulness variable and the Intention To Use variable with a T-Statistic value of $3.407>1.96$, then $\mathrm{H} 1$ is accepted, so it can be concluded that Hypothesis 1 is proven.

(2) There is a significant relationship between the Perceived Usefulness variable and the Attitude Towards Using variable with a T-Statistic value of $6.150>1.96$, then $\mathrm{H} 2$ is accepted, so it can be concluded that Hypothesis 2 is proven.

(3) There is a significant relationship between the Perceived Ease of Use variable and the Attitude Towards using variable with a T-Statistic value of $4.074>1.96$, then $\mathrm{H} 3$ is accepted, so it can be concluded that Hypothesis 3 is proven. 
(4) There is a significant relationship between the Perceived Ease of Use variable and the Perceived Usefulness variable with a T-Statistic value of $10.145>1.96$, so H4 is accepted, so it can be concluded that Hypothesis 4 is proven.

(5) There is a significant relationship between the Attitude Towards Using variable and the Intention To Use variable with a T-Statistic value of $5.616>1.96$, then H5 is accepted, so it can be concluded that Hypothesis 5 is proven.

\section{Technology and Behavior Change}

Based on the data processing above, this study explains that the presence of technological media shapes human behavior. In an era of rapid technological development like today, media such as smartphones, laptops, etc. are intermediaries to facilitate the delivery of messages or information. Over time, messages conveyed through the media are no longer a factor in changing one's behavior but the media itself.

In this study, the concept is linked to the context of students with online learning situations using the Microsoft Teams platform used by Universitas Tarumanagara during the current Covid-19 pandemic and can be linked to an explanation of the global village. The global village concept states that the dissemination of information has no limits due to the existence of the media. This shows that in today's learning system which requires it to be done online, direct attendance in class (face to face) is no longer a problem. Wherever students and lecturers are, it does not affect the teaching and learning process because of the media in accessing applications using the internet such as Microsoft Teams which is a tool in the online learning process.

In the context of this research, media ecology theory can be related to TAM theory about the ease and usability of technology such as the Microsoft Teams platform. This allows students to become accustomed to using technology and these habits shape behaviors that support the attitudes that will be demonstrated later in using the Microsoft Teams platform. This attitude also determines the students' intention to reuse the Microsoft Teams platform in their life or vice versa. This is what is called a behavioral change related to media ecology.

\section{Distance Learning Communication Media}

In today's modern era, everyone uses communication media as a tool to exchange messages, socialize with each other through online social media, and so on. One of the uses of communication media that plays an important role in accordance with the current conditions of the Covid-19 pandemic is conducting online forum activities, such as webinars, meetings, distance learning systems that cannot be done face-to-face and can only be done from home only. The use of communication media in this study is related to the online learning system, where Universitas Tarumanagara students must use the Microsoft Teams platform by using electronic devices as a substitute for offline learning media so as not to hinder the teaching and learning process. The theory of Computer Mediated Communication says that the development of a communication relationship is used through text-based communication. The Microsoft Teams platform used in this study is a text-based platform coupled with interactive video capabilities.

This study uses the theory of Computer Mediated Communication to see the use of communication media in Universitas Tarumanagara students. Based on the results of research using a questionnaire, most of Universitas Tarumanagara students use mobile phones and laptops to access the internet where all activities carried out online must use the internet to be accessed including opening the Microsoft Teams platform. This states that the media is needed as an intermediary in helping communications that are built while doing or following activities carried out online.

\section{Acceptance of Microsoft Teams in Learning Systems}

The TAM model in this study has been tested and all the variables used show significant results so that it can show that there is an influence between the ease of using Microsoft Teams and the benefits of using Microsoft Teams on student attitudes and behavior in using Microsoft. Team, especially during the Covid-19 pandemic. Currently that requires Universitas Tarumanagara students to do distance learning (online).

The presence of Microsoft Teams can reduce problems in carrying out teaching and learning activities. In addition, Microsoft Teams is also a solution for students that is useful for replacing offline learning systems in the current situation where face-to-face is not possible. The attitudes and behavior of Universitas Tarumanagara students, seen from the results of their research, show that students accepted the use of Microsoft Teams as a platform used in the online learning system at Universitas Tarumanagara during the Covid-19 pandemic.

\section{CONCLUSIONS}

Based on the results of data processing from the Technology Acceptance Model, this study concludes that there is an effect of the use of Microsoft Teams on Attitude Towards Using, Perceived Usefulness, and Perceived Ease of Use of Universitas Tarumanagara students during the Covid-19 pandemic. The results of data processing also show that there is an effect of using Microsoft Teams on the Intention To Use of Universitas Tarumanagara students during the Covid-19 pandemic. The results of the study stated that 
students had good behavior intentions to use the Microsoft Teams platform as an online learning system during the Covid-19 pandemic set by Universitas Tarumanagara.

Media Ecology Theory if it is related to the online learning system due to the current Covid-19 pandemic, no influencing the interaction between students and lecturers in the online teaching and learning process because of the media used to access applications such as the Microsoft Teams platform. Other than that, in the theory of Computer Mediated Communication is associated with the media used with the results of the research saying that the media for mobile phones and laptops to access the internet network are the most widely used by students to open the Microsoft Teams platform to facilitate communication between lecturers and students of Universitas Tarumanagara during the online teaching and learning process in the situation of Covid-19 pandemic.

Researchers suggest that further research that wants to discuss or have a similar topic to this research, namely using the Technology Acceptance Model (TAM) theory, can discuss broadly or more deeply because TAM has not been discussed much and is still relatively small in the aspect of communication science. Apart from that, in conducting research using the TAM theory, the researchers do not only research in the technical aspects, but can be raised which leads to the philosophical aspects by adding other theories that can be linked or combined with the TAM theory. The aim is to enrich the research made so that it can describe actual phenomena or those related to the present in accordance with human behavior towards the use of technology in line with technological developments that continue to develop very rapidly.

\section{ACKNOWLEDGMENT}

This research was not funded by anybody. In addition, the researchers also offer Praise and Gratitude to God Almighty because His blessings and Mercy the author can finish this research well. Researchers want to thank the supervisor and cosupervisor who have guided researchers in compiling this research. Researchers also want to thank the respondents who helped fill out the questionnaire.

\section{REFERENCES}

[1] M. Sucahya, "Teknologi komunikasi dan media," $J$. Komun., vol. 1, no. 2, pp. 6-22, 2013.

[2] W. Hartanto, "Penggunaan E-Learning Sebagai Media Pembelajaran," J. Pendidik. Ekon. J. Ilm. Ilmu Pendidikan, Ilmu Ekon. dan Ilmu Sos., vol. 10, no. 1, 2016.
[3] S. A. Hapsari and H. Pamungkas, "Pemanfaatan google classroom sebagai media pembelajaran online di universitas dian nuswantoro," 2019. https://doi.org/10.32509/wacana.v18i2.924

[4] M. Ratana, "Pengaruh Social Media Marketing Terhadap Ekuitas Merek," J. Stud. Komun. dan Media, vol. 22 , no. $1,2018$.

[5] N. Izzati, "Motif penggunaan gadget sebagai sarana promosi bisnis online di kalangan mahasiswa UIN Sunan Kalijaga,” J. Aspikom, vol. 2, no. 5, pp. 374-380, 2015.

[6] S. H. Arnus, "Pengaplikasian Pola Computer Mediated Communication (CMC) dalam Dakwah," J. Jurnalisa J. Jur. Jurnalistik, vol. 4, no. 1, 2019. https://doi.org/10.24252/jurnalisa.v4i1.5618

[7] J. B. Walther, B. Van Der Heide, A. Ramirez, J. K. Burgoon, and J. Peña, "Interpersonal and hyperpersonal dimensions of computer-mediated communication," Handb. Psychol. Commun. Technol., vol. 1, p. 22, 2015.

[8] I. M. FATMAWATI, "HUBUNGAN KOMUNIKASI HIPERPERSONAL DENGAN PEMELIHARAAN HUBUNGAN JARAK JAUH (LONG DISTANCE RELATIONSHIP) PASANGAN SUAMI ISTRI DI KOTA BANDUNG." PERPUSTAKAAN, 2017. http://repository.unpas.ac.id/30534/

[9] A. Al-Adwan, A. Al-Adwan, and J. Smedley, "Exploring students acceptance of e-learning using Technology Acceptance Model in Jordanian universities," Int. J. Educ. Dev. using ICT, vol. 9, no. 2, 2013

[10] Sugiyono, Metode Penelitian Kuantitatif, Kualitatif, dan R\&D. Bandung: Alfabeta. 2017.

[11] V. G. Hair Jr, J. F., Sarstedt, M., Hopkins, L., \& Kuppelwieser, Partial least squares structural equation modeling (PLS-SEM). 2014.

[12] Sudarto, "Difusi Berita Politik Dan Pembentukan Opini Publik Di Era Media Sosial," Ilmu Sos. Dan Polit. Univ. Indones., 2018. 